\title{
New and interesting lichen records from the Ural Mountains, Russia
}

\author{
Alexander G. Paukov ${ }^{1}$, Lyudmila V. Gagarina ${ }^{2} \&$ Ivan V. Frolov $^{3}$ \\ ${ }^{1}$ Institute of Natural Sciences and Mathematics, Ural Federal University, Lenin av. 51, 620000 Ekaterinburg, Russia. \\ E-mail: alexander_paukov@mail.ru \\ ${ }^{2}$ V.L. Komarov Botanical Institute RAS, Prof. Popova str. 2, 197376 St. Petersburg, Russia. E-mail: gagarinalv@binran.ru \\ ${ }^{3}$ Department of Botany, Faculty of Science, University of South Bohemia, Branišovská 31, České Budějovice, CZ-37005, \\ Czech Republic. E-mail: ivfrolov@gmail.com
}

\begin{abstract}
Ten species of lichenized ascomycetes are reported from the Urals. Aspicilia spermatomanes, Fuscidea praeruptorum, Lepra excludens, L. monogona, Metamelanea caesiella and Pertusaria amarescens are new to Russia while Bryobilimbia ablesii, Lecanora orosthea, L. rouxii and Tephromela grumosa are new for the Urals. Our records considerably extend the ranges or fill gaps in the formerly disjunctive distributions of these species. The morphology, secondary chemistry and ecology of the species are discussed.
\end{abstract}

Keywords: saxicolous lichens; range extension; biodiversity

\section{INTRODUCTION}

The lichen flora of the Ural mountains has been extensively studied during the last decades (Paukov, 1999; Frolov, 2008; Urbanavichus \& Urbanavichene, 2011; Paukov \& Teptina, 2012; Dudoreva et al., 2014; Vondráková \& Vondrák, 2015); however, the lichen biodiversity of the region is far from being completely known.

The longitudinal range of the Ural Mountains together with high altitudes brings about a complicated climatic and vegetational zonation of the territory (Gorchakovskiy, 1966) producing, together with different rock types, a variety of habitats for lichens. Vegetation on the eastern slopes of the Middle Urals consists of coniferous forests with pine (Pinus sylvestris L.) gradually changing to birch (Betula pendula Roth) forests and finally to steppe vegetation in the Southern Urals. On the western slopes the predominant vegetation is fir (Picea obovata Ledeb.) forests with an admixture of spruce (Abies sibirica Ledeb.), linden (Tilia cordata Mill.) and other deciduous trees.

The high mountains in the Southern Urals above 900 m usually bear azonal vegetation such as patches of mountain tundra or vegetation with stunted larch and birch (Kucherov \& Muldashev, 1988; Kulikov, 2010). Lichenological investigations of these territories were focused mainly on lichens as a source of food for animals (Selivanova-Gorodkova, 1965) or on studies of vegetation and phytomonitoring (Gorchakovskiy $\&$ Shiyatov, 1985); special research of the lichen diversity gave a number of interesting findings (Urbanavichene, 2011). Here we report new records of lichens mainly from the high altitudes in the Southern and Middle Urals which are new to Russia or known previously in its westernmost parts, and which substantially extend their ranges to the east.

\section{MATERIAL AND METHODS}

Lichens were collected at 6 localities in Sverdlovsk and Chelyabinsk regions and in the Republic of Bashkortostan by the authors. The collections were made in 1993-2016. The visited localities and collectors are as follows:

1. Sverdlovsk region, Nizhne-Serginsk district, vicinity of Bazhukovo village, Nature Park “Olen'ji Ruchji”, 56 $31^{\circ} \mathrm{N}, 5^{\circ} 15^{\prime} \mathrm{E}$, A. Paukov.

2. Chelyabinsk region, Zlatoust district, Na-

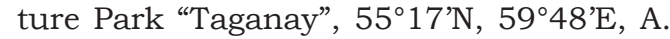
Paukov.

3. Chelyabinsk region, Vicinity of Miass town, Ilmenskiy Nature reserve, $55^{\circ} 17^{\prime} \mathrm{N}, 60^{\circ} 28^{\prime} \mathrm{E}$, A. Paukov.

4. Republic of Bashkortostan, Beloretsk district, Yuzhno-Uralskiy Nature reserve, $54^{\circ} 18^{\prime} \mathrm{N}, 57^{\circ} 62^{\prime} \mathrm{E}, \mathrm{A}$. Paukov and L. Gagarina.

5. Republic of Bashkortostan, Abzelilovo district, Kryktytau mountain range, Khandyk mountain, $53^{\circ} 42^{\prime} \mathrm{N}, 58^{\circ} 36^{\prime} \mathrm{E}$, A. Paukov. 
6. Republic of Bashkortostan, Abzelilovo district, Baskirskiy state reserve, $5 \mathrm{~km}$ to the North from Kolgana (Kulganino) village, $53^{\circ} 23^{\prime} \mathrm{N}, 57^{\circ} 55^{\prime} \mathrm{E}$, I. Frolov.

The species were identified using stereo- and compound microscopes. The determination of lichen substances was conducted using thin layer chromatography (TLC) in solvent systems A and C (Orange et al., 2001). The specimens are kept in UFU and some specimens were sent to LE.

\section{LIST OF SPECIES}

Symbols used: * - species new to Russia, ** species new to Urals.

*Aspicilia spermatomanes (Nyl.) Maheu et Gillet - 3: granite outcrops under forest canopy near Bolshoye Miassovo Lake, 12.08.2013; 6: serpentinite outcrops along Karasu brook, 12.06.2004 (UFU L-1289).

Note. The species is described and known previously from France only (Roux et al., 2011). It differs from Aspicilia cinerea (L.) Körb. by the thick rimose-areolate thallus with finally large, flat, irregular "areoles" more than $2 \mathrm{~mm}$ wide, which have small tubercules on their surface (Fig. 1). These tubercules correspond to areoles in Aspicilia cinerea. Apothecia are formed mainly as primordia and have undeveloped spores in the asci. Pycnidia are abundant to rare in specimens with apothecial primordia, with pycnoconidia (10) 14-16 (18) $\mu \mathrm{m}$ long. In Nylander's view Aspicilia spermatomanes is a variation of

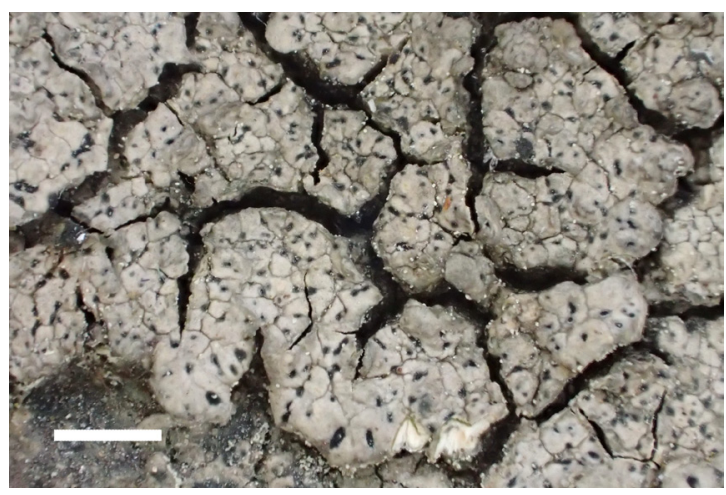

Fig. 1. Aspicilia spermatomanes (UFU L-1289), thallus with apothecial primordia. Scale bar = $2 \mathrm{~mm}$.
Lecanora (Aspicilia) cinerea (Nylander, 1872a), but we follow the views of Maheu \& Gillet (1926) and Roux et al. (2011). The two species were found growing closely together and can be easily separated from each other. We did not manage to produce ITS sequences from the specimens collected, but our preliminary data on mtSSU of Aspicilia cinerea and A. spermatomanes found in the Urals suggest that they are separate species.

**BRyobilimbia Ahlesil (Körb.) Fryday, Printzen \& S. Ekman - 4: shaded sandstone outcrops on the left bank of River Inzer between Revet' and the former Kataskin settlement, 02.08.2015.

Note. The species is known from the Czech Republic, Finland, Germany, Ireland, Latvia, Sweden and USA (Arup, 2004; Coppins \& Fryday, 2006; Halda et al., 2011; Fryday et al., 2014; Motiejūnaitè \& Grochowski, 2014). In Russia it is reported from the Caucasian region and northern European part (Urbanavichus, 2010). Although not very prominent, this species can be recognised by the $\mathrm{K}+$ violet greenish granules in the hymenium together with the thin thallus, simple spores and dark hypothecium.

*Fuscidea praeruptorum (Du Rietz \& H. Magn.) V. Wirth \& Vězda - 2: shaded quarzite rocks on "Dvuglavaya Sopka" mountain, 01.07.2014.

Note. The species is widely distributed in Europe (Asta, 1972; Wirth \& Vězda, 1972; Nimis \& Tretiach, 1993; Fryday \& Coppins, 1997; Vitikainen et al., 1997; Jüriado et al., 2000; Nordin et al., 2011; Motiejūnaite, 2015) and is also known from Turkey (Karabulut et al., 2004). Fuscidea praeruptorum contains alectorialic acid which reacts with $\mathrm{P}$ and $\mathrm{C}$ and imparts a yellowish tint to the soralia. The species grows on the sides of large boulders formed by frost weathering of quarzite.

**LeCANORA OROSTHEa (Ach.) Ach. - 4: porphyrite rocks on the Yusha range, 05.08.2015.

Note. The species is known from Central and Northern Europe, Africa (Zduńczyk \& Kukwa, 2014), Turkey (John \& Breuss, 2004) and Hong Kong (Aptroot \& Seaward, 1999). In Russia it is recorded from Karelia (Kopaczevskaja et al., 1971). Lecanora orosthea is a species growing on shaded vertical rocks. It can be recognised by the yellowish thalli with soredia that first develop on the margins of the areoles and later 
fuse together to form a sorediate crust. Secondary substances in the specimens from the Urals are usnic acid and zeorin.

**LECANORA ROUXII S. Ekman \& Tønsberg - 4: 3 $\mathrm{km} \mathrm{W}$ of Berdagulovo settlement, left bank of Inzer River, on carbonised slate, 06.08.2015.

Note. The species is distributed in France, Germany, Norway (Tønsberg, 2002), Poland (Kukwa, 2005) and Romania (Vondrák \& Šoun, 2007). In Russia it was previously known from the Kaliningrad region only (Urbanavichus, 2010). Lecanora rouxii is very similar to species of the genus Lepraria, in which it was originally placed, but it differs from any Lepraria species by containing sordidone, which gives a $\mathrm{C}+$ orange reaction, and atranorin. In the Ural Mountains it is so far only known from the cited locality, where it grows on steep highly carbonised slate rocks together with other calciphilous species, such as Caloplaca saxicola (Hoffm.) Nordin, Diplotomma alboatrum (Hoffm.) Flot., Leproplaca cirrochroa (Ach.) Arup et al., Peccania coralloides (A. Massal.) A. Massal.; however, it is absent on limestone in the neighbouring localities.

*LePRa excludens (Nyl.) Hafellner (syn. Pertusaria excludens Nyl.) - 4: porphyrite rocks on the Yusha range, 05.08.2015.

Note. The species is known from Antarctica, Austria, Finland, France, Germany, Norway, Portugal, Spain and USA (Thomson, 1997; Llimona \& Hladun, 2001; Øvstedal \& Lewis Smith, 2001; Nordin et al., 2011; Roux, 2012; Wirth et al., 2013; Hafellner \& Türk, 2016). Lepra excludens is reported from several regions of Russia but these reports are regarded as doubtful (Urbanavichus, 2010). Given the unreliability of these records, the species is considered to be new to Russia. It has a relatively thick whitishgrey thallus with rounded soralia. The secondary metabolite is norstictic acid.

*Lepra monogona (Nyl.) Hafellner (syn. Pertusaria monogona Nyl.) - 5: basaltic rocks on the Khandyk mountain, 19.08.1993; ibidem, 28.05.2010 (UFU L-1224), det. A. Archer.

Note. The species is distributed in Europe (Nylander, 1872b; Seaward, 1994; Coppins, 2002), Northern Africa (Egea et al., 1990) and China (Zhao et al., 2004). It is common at the locality but was for a long time misidentified as Per- tusaria stalactizoides Savicz. The latter species was described from the Northern Urals and, apart from the yellowish thallus, agrees with the characters of $L$. monogona. This similarity brings about confusion at times (Zhao et al., 2004). The type of $P$. stalactizoides could not be traced at $\mathrm{LE}$ and therefore it is currently not possible to confirm the identity of these two species. L. monogona has a thick thallus, pruinose apothecia, single-spored asci, large spores, up to $300 \mu \mathrm{m}$ long, and contains norstictic acid (Fig. 2).

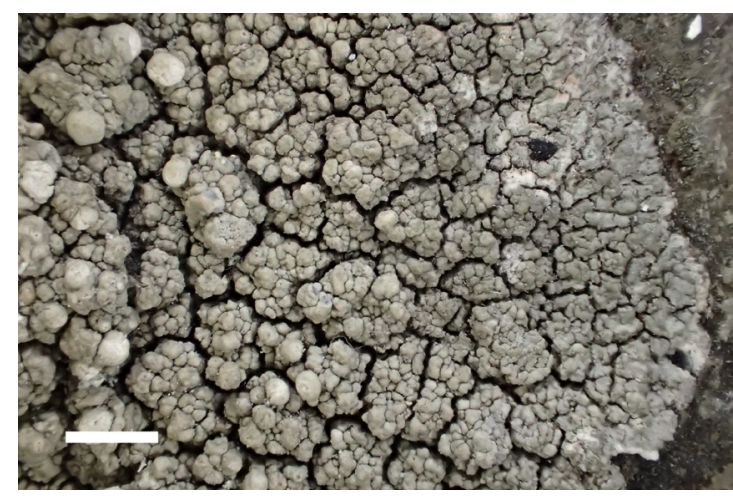

Fig. 2. Lepra monogona (UFU L-1224), thallus and apothecia. Scale bar $=2 \mathrm{~mm}$.

*Metamelanea caesiella (Th. Fr.) Henssen - 1: limestone outcrops on Serga river, on limestone, 20.08.2011.

Note. This crustose cyanobiont lichen is noticeable by the formation of bluish-pruinose patches in rock crevices on limestone (Schultz \& Büdel, 2002). The areoles are tiny and vertically elongated, which imparts a dwarf-fruticulose appearance to the lichen. The apothecia are blackish and adnate, with prominent margins. M. caesiella has a scattered distribution and is known from Belgium, the Czech republic, France, Germany and Norway (Henssen \& Jørgensen, 1990; Ertz et al., 2008; Roux, 2012; Wirth et al., 2013; Malíček et al., 2014). In the Urals it was found on wet calcareous rocks and is so far known from only one locality. The fact that this species is rarely fertile and is difficult to identify in the sterile condition (Ahti et al., 2007) may be a reason for its alleged rarity.

*Pertusaria amarescens Nyl. - 4: $3 \mathrm{~km}$ to $\mathrm{W}$ from Berdagulovo settlement, left bank of Inzer River, on carbonised slate, 06.08.2015. 
Note. The species is known from Western Europe, China, India and the French Antarctic Territories (Llimona \& Hladun, 2001; Coppins, 2002; Upreti et al., 2004; Aptroot et al., 2011; Wirth et al., 2013). The thalli of Pertusaria amarescens found in the Urals appear similar to Lepra (Pertusaria) albescens (Huds.) Hafellner but differ chemically by containing thiophaninic acid together with stictic acid and therefore have a yellowish tinge. P. amarescens was found on calcareous slate growing with Lecanora rouxii.

**Tephromela grumosa (Pers.) Hafellner \& Cl. Roux - 5: basaltic rocks on the Khandyk mountain, 11.06.2016.

Note. A conspicious lichen which can be easily recognised by its Lecanora-like thallus with bluish- or greenish grey soralia. The thalli contain atranorin and protolichesterinic acid. T. grumosa is known from Austria, Finland, France, Germany, Norway and Sweden (Nordin et al., 2011; Roux, 2012; Wirth et al., 2013; Westberg et al., 2015; Hafellner \& Türk, 2016). In Russia the species was previously reported from the Murmansk region, Karelia, the Far East and Kamchatka (Andreev et al., 2003). Prior to our findings, the distribution of the species was regarded as nordic and montane, with a preference for maritime regions. In the Urals it was found above $900 \mathrm{~m}$ at a locality with high precipitation.

\section{DISCUSSION}

Six of the species reported here - Aspicilia spermatomanes, Fuscidea praeruptorum, Lepra excludens, L. monogona, Metamelanea caesiella and Pertusaria amarescens - are new to Russia. Four species - Bryobilimbia ahlesii, Lecanora orosthea, L. rouxii and Tephromela grumosa-are new to the Urals. All species reported here are new records which noticeably stand out from their previously known distributions. Aspicilia spermatomanes, Bryobilimbia ahlesii, Fuscidea praeruptorum, Lecanora rouxii, Lepra excludens, Metamelanea caesiella and Tephromela grumosa have their easternmost localities in the Urals, while the others fill distributional gaps between localities in Europe and Asia.

With the addition of these species, the biodiversity of saxicolous lichens (including epigeic species permanently occurring in saxicolous environments, such as Cladoniaceae and Peltigeraceae) in the Middle and Southern Urals currently comprises above 550 species. This is twice higher than reported from the Middle Urals in our previous papers (Paukov \& Trapeznikova, 2005; Paukov, 2009), but so far quite moderate compared to well-studied mountainous regions in Eurasia. The discovery of species with ranges extending to the Urals and distant from their previously known distributions will help to improve our knowledge of the lichen diversity of the region.

\section{ACKNOWLEDGEMENTS}

We are very grateful to Alan Archer (Royal Botanical Garden, Sydney, Australia) for his help and suggestions in determination of Pertusariaceae as well as linguistic corrections. The authors would like to thank Matthias Schultz (University of Hamburg, Germany) for checking the determination of Metamelanea caesiella. We would like to express our gratitude to Tiina Randlane and anonymous reviewer for improving of the manuscript. This study is supported by RFBR (projects 15-04-05971 and 17-44-220321).

\section{REFERENCES}

Ahti, T., Jørgensen, P. M., Kristinsson, H., Moberg, R., Søchting, U. \& Thor, G. (eds). 2007. Nordic Lichen Flora Vol. 3. Cyanolichens. Nordic Lichen Society, Uddevalla. 219 pp.

Andreev, M. P., Bredkina, L. I., Golubkova, N. S., Dobrysh, A. A., Kotlov, Y. V., Makarova, I. I., Urbanavichene, I. N. \& Urbanavichus, G. P. 2003. Handbook of the Lichens of Russia. 8. Bacidiaceae, Catillariaceae, Lecanoraceae, Megalariaceae, Mycobilimbiaceae, Rhizocarpaceae, Trapeliaceae. St. Petersburg. 277 pp. (In Russian).

Aptroot, A. \& Seaward, M. R. D. 1999. Annotated checklist of Hong Kong lichens. Tropical Bryology 17: 57-101.

Aptroot, A., van de Vijver, B., Lebouvier, M. \& Ertz, D. 2011. Lichens of Ile Amsterdam and Ile Saint Paul (TAAF, southern Indian Ocean). Nova Hedwigia 92(3-4): 343-367. https://doi. org/10.1127/0029-5035/2011/0092-0343

Arup, U. 2004. Three overlooked Lecidea species in Sweden. Symbolae Botanicae Upsalienses 34(1): 39-48.

Asta, J. 1972. Lecidea praeruptorum DR. et Magn. et Physconia detersa (Nyl.) Poelt: deux lichens interessants pour la flore Francaise. Bull. Soc. Bot. France 119: 127-132. https://doi.org/10.1080/ 00378941.1972 .10839012

Coppins, B. J. 2002. Checklist of Lichens of Great Britain and Ireland. British Lichen Society. 87 pp. 
Coppins, B. J. \& Fryday, A. M. 2006. Reassessment of some lichen species described by Josiah Lowe, and notes on some other North American lecideoid lichens. The Bryologist 109(1): 9-17. https:/ / doi. org/10.1639/0007-2745(2006)109[0009:ROSLS D]2.0.CO;2

Dudoreva, T. A., Melekhin, A. V. \& Lagunov, A. V. 2014. On the flora of lichens of Ilmenskiy Nature Reserve. Vestnik Orenburgskogo Gosudarstvennogo Universiteta 6: 18-22. (In Russian).

Egea, J. M., Torrente, P. \& Rowe, J. G. 1990. Contribucion a la flora de Argelia y Tunez: liquenes y hongos lichenicolas. Cryptogamie, Bryologie et Lichenologie 11(4): 409-417.

Ertz, D., Diederich, P., van den Boom, P. \& Sérusiaux, E. 2008. New or interesting lichens and lichenicolous fungi from Belgium, Luxembourg and northern France. XI. Bulletin de la Société des Naturalistes Luxembourgeois 109: 35-51.

Frolov, I. V. 2008. Epilithic lichens of Bashkirsky Nature Reserve. Novitates Systematicae Plantarum Non Vascularium 42: 219-224. (In Russian).

Fryday, A. \& Coppins, B. 1997. Keys to sterile, crustose saxicolous and terricolous lichens occurring in the British Isles. The Lichenologist 29(4): 301-332. https://doi.org/10.1017/S0024282997000388

Fryday, A. M., Printzen, C. \& Ekman, S. 2014. Bryobilimbia, a new generic name for Lecidea hypnorum and closely related species. The Lichenologist 46(1): 25-37. https://doi.org/10.1017/ S0024282913000625

Gorchakovskiy, P. L. 1966. Flora and vegetation of high mountains in the Urals. Trudy Instituta Biologii 48: 1-270. (In Russian).

Gorchakovskiy, P. L. \& Shiyatov, S. G. 1985. Phytoindication of environmental conditions and natural processes in the highlands. Moscow. 208 pp. (In Russian).

Hafellner, J. \& Türk, R. 2016. Die lichenisierten Pilze Österreichs - eine neue Checkliste der bisher nachgewiesenen Taxa mit Angaben zu Verbreitung und Substratökologie. Stapfia 104(1): 1-216.

Halda, J. P., Bouda, F., Fessová, A., Kocourková, J., Malíček, J., Müller, A., Peksa, O., Svoboda, D., Šoun, J. \& Vondrák, J. 2011. Lichens recorded during the autumnal bryo-lichenological meeting in Železné hory Mts (Czech Republic), September 2009. Bryonora 47: 40-51.

Henssen, A. \& Jørgensen, P. M. 1990. New combinations and synonyms in the Lichinaceae. The Lichenologist 22(2): 137-147. https://doi. org/ 10.1017/S0024282990000093

John, V. \& Breuss, O. 2004. Flechten der östlichen Schwarzmeer-Region in der Türkei (BLAM-Exkursion 1997). Herzogia 17: 137-156.

Jüriado, I., Lõhmus, P. \& Saag, L. 2000. Supplement to the second checklist of lichenized, lichenicolous and allied fungi of Estonia. Folia Cryptogamica Estonica 37: 21-26.
Karabulut, S. N., Ozdemir-Turk, A. \& John, V. 2004. Lichens to monitor afforestation effects in Canakkale, Turkey. Cryptogamie, Mycologie 25(4): 333-346.

Kopaczevskaja, E. G., Makarevich, M. F., Oxner, A. N. \& Rassadina, K. A. 1971. Handbook of the lichens of the USSR. 1. Pertusariaceae, Lecanoraceae and Parmeliaceae. Leningrad. 410 pp. (In Russian).

Kucherov, E. V., Muldashev, A. A. (eds). 1988. Handbook of vascular plants of Bashkirian Autonomous Republic. 1. Moscow. 316 pp. (In Russian).

Kukwa, M. 2005. Notes on the chemistry and distribution of Lecanora rouxii (lichenized Ascomycota) in Poland. Botanica Lithuanica 11(3): 161-166.

Kulikov, P. V. 2010. Handbook of vascular plants of Chelyabinsk region. Yekaterinburg. 969 pp. (In Russian).

Llimona, X. \& Hladun, N. L. 2001. Checklist of the lichens and lichenicolous fungi of the Iberian Peninsula and Balearic Islands. Bocconea 14: 1-581.

Maheu, J. \& Gillet, A. 1926. Lichens de l'est de la Corse. Dijon. 114 pp.

Malíček, J., Palice, Z. \& Vondrák, J. 2014. New lichen records and rediscoveries from the Czech Republic and Slovakia. Herzogia 27: 257-284. https://doi. org/10.13158/heia.27.2.2014.257

Motiejūnaite, J. 2015. Lichens and allied fungi from the Cepkeliai State Nature Reserve (Southern Lithuania). Botanica Lithuanica 21(1): 3-12. https:// doi.org/10.1515/botlit-2015-0001

Motiejūnaitė, J., \& Grochowski, P. 2014. Miscellaneous new records of lichens and lichenicolous fungi. Herzogia 27(1): 193-198. https://doi. org/10.13158/heia.27.1.2014.193

Nimis, P. L. \& Tretiach, M. 1993. A contribution to lichen floristics in Italy. Bollettino del Museo Regionale di Scienze Naturali - Torino 11(1): 1-45.

Nordin, A., Moberg, R., Tønsberg, T., Vitikainen, O., Dalsätt, Å., Myrdal, M., Snitting, D. \& Ekman, S. 2011. Santesson's Checklist of Fennoscandian Lichen-forming and Lichenicolous Fungi. Ver. April 29, 2011 http://130.238.83.220/santesson/home.php (30 March 2017).

Nylander, W. 1872a. Observata lichenologica in Pyrenaeis orientalibus. II. La Preste-Costabonne. Flora (Regensburg) 55: 545-554.

Nylander, W. 1872b. Observata lichenologica in Pyrenaeis orientalibus. Bulletin de la Société linnéenne de Normandie, ser. 2 6: 256-328.

Orange, A., James, P. W. \& White, F. J. 2001. Microchemical methods for the identification of lichens. British Lichen Society. 101 pp.

Øvstedal, D. O. \& Lewis Smith, R. I. 2001. Lichens of Antarctica and South Georgia: A guide to their identification and ecology. Cambridge. $411 \mathrm{pp}$.

Paukov, A. G. 1999. On the records of Caloplaca grimmiae (Nyl.) Oliv. in the Middle Urals. Botanicheskii Zhurnal 84: 136-137. (In Russian). 
Paukov, A. G. 2009. The lichen flora of serpentine outcrops in the Middle Urals of Russia. Northeastern Naturalist 16 (Special Issue 5): 341-350.

Paukov, A. G. \& Teptina, A. Yu. 2012. New records of lichens from Middle Urals, Russia. Folia Cryptogamica Estonica 49: 39-43.

Paukov, A. G. \& Trapeznikova, S. N. 2005. Lithophilous lichens of Middle Urals. Folia Cryptogamica Estonica 41: 81-88.

Roux, C. 2012. Liste des lichens et champignons lichénicoles de France. Bulletin de la Société linnéenne de Provence Numéro spécial 16: 1-220.

Roux, C., Nordin, A., Tibell, L. \& Sohrabi, M. 2011. Quelques espèces d'Aspicilia peu connues ou nouvelles des Pyrénées-Orientales (France). Bulletin de la Société Linnéenne de Provence, num. spéc. 14: 177-227.

Schultz, M. \& Büdel, B. 2002. Key to the genera of the Lichinaceae. The Lichenologist 34(1): 39-62. https://doi.org/10.1006/lich.2001.0367

Seaward, M. R. D. 1994. Vice-county distribution of Irish lichens. Biology and Environment: Proceedings of the Royal Irish Academy 94B(2): 177-194.

Selivanova-Gorodkova, E. A. 1965. Epiphytic lichens as an additional forage source for wild ungulates in the Southern Urals. Trudy Instituta Biologii UFAN USSR 42: 113-120. (In Russian).

Thomson, J. W. 1997. American Arctic Lichens. 2. The Microlichens. Madison. 675 pp.

Tønsberg, T. 2002. Notes on non-corticolous Lepraria s. lat. in Norway. Graphis Scripta 13(2): 45-51.

Upreti, D. K., Chatterjee S. \& Divakar P. K. 2004. Additions to the lichen flora of Sikkim, India. In: Srivastava R. (ed). Vistas in Paleobotany and Plant Morphology: Evolutionary and Environmental Perspectives (Professor D. D. Pant Memorial Volume). Lucknow. P. 329-338.

Urbanavichene, I. N. 2011. First data on lichens of Zyuratkul national park (Chelyabinsk region). Novitates Systematicae Plantarum Non Vascularium 45: 223-236. (In Russian).
Urbanavichus, G. 2010. A checklist of the lichen flora of Russia. St. Petersburg. 194 pp.

Urbanavichus, G. \& Urbanavichene, I. 2011. New records of lichens and lichenicolous fungi from the Ural Mountains, Russia. Folia Cryptogamica Estonica 48: 119-124.

Vitikainen, O., Ahti, T., Kuusinen, M., Lommi, S. \& Ulvinen, T. 1997. Checklist of lichens and allied fungi of Finland. Norrlinia 6: 1-123.

Vondrák, J. \& Šoun, J. 2007. Some newly recorded and noteworthy lichen-forming and lichenicolous fungi from Romania. Acta Botanica Hungarica 50: 215-221. https://doi.org/10.1556/ ABot.50.2008.1-2.16

Vondráková, O. S., Vondrák, J. 2015. Some new lichen records from the Orenburg Region. Novitates Systematicae Plantarum Non Vascularium 49: 231-238. (In Russian).

Westberg, M., Timdal, E., Asplund, J., Bendiksby, M., Haugan, R., Jonsson, F., Larsson, P., Odelvik, G., Wedin, M. \& Millanes, A. M. 2015. New records of lichenized and lichenicolous fungi in Scandinavia. Mycokeys 11: 33-61. https://doi.org/10.3897/ mycokeys. 11.6670

Wirth, V. \& Vězda, A. 1972. Zur Systematik der Lecidea cyathoides-Gruppe. Beitrage Naturk. Forsch. Sudw.-Deutschl. 31: 91-92.

Wirth, V, Hauck, M. \& Schultz, M. 2013. Die Flechten Deutschlands. Band 2. Stuttgart. 1244 pp.

Zduńczyk, A. \& Kukwa, M. 2014. A revision of sorediate crustose lichens containing usnic acid and chlorinated xanthones in Poland. Herzogia 27(1): 1340. https://doi.org/10.13158/heia.27.1.2014.13

Zhao, Z.-T., Ren, Q. \& Aptroot, A. 2004. An annotated key to the lichen genus Pertusaria in China. The Bryologist 107(4): 531-541. https://doi. org/ 10.1639/0007-2745(2004)107[531:AAKTT $\mathrm{L}] 2.0 . \mathrm{CO} ; 2$ 